\title{
Effective Commands to Overcome Students with Disruptive Behavior in the Classroom
}

\author{
Luh Kade Diana Kusumadewi \\ Ganesha University of Education, Singaraja, Indonesia \\ kadedianaa@gmail.com \\ Luh Diah Surya Adnyani \\ Ganesha University of Education, Singaraja, Indonesia \\ surya.adnyani@undiksha.ac.id \\ Ni Putu Astiti Pratiwi \\ Ganesha University of Education, Singaraja, Indonesia \\ astitipratiwi@undiksha.ac.id
}

\begin{abstract}
This study was conducted which aimed at investigating effective commands used by teachers in TK Aura Sukma Insani to overcome disruptive behaviors by identifying: 1) the types of disruptive behavior done by students, 2) the types of command used by the teachers, and 3) the commands which are effective based on students' responses. Teachers and students from A2, A1, and toddler class were the subject of the study while disruptive behaviors done by the students and commands used by the teacher were the object of the study. All the data were gathered through observation, questionnaire, and interview. The result revealed that there were 145 disruptive behaviors found and seven type of commands used by the teachers including question command, regular command, indirect command, don't command, stop command, negative command and other command. Moreover, most of the commands given were effective based on the effects on students' behavior. From the result, it could be concluded that regular command and other command were the most effective types of command used by teachers to overcome disruptive behaviors because the commands related were clear, understandable, and simple. Therefore, the student were easy to understand what the teachers intended.
\end{abstract}

Keywords: disruptive behavior; effective command; kindergarten teacher

ENGLISH FRANCA : Academic Journal of English Language and Education

Vol.4, No.2, 2020, IAIN Curup

P-ISSN2580-3670, E-ISSN2580-3689

DOI: http://dx.doi.org/10.29240/ef.v4i2.1822, Page 181-202 


\section{INTRODUCTION}

Based on categories of government regulation Nomor 84 Tahun 2014, a kindergarten is a form of early childhood formal education that organizes a program for children to take education from the age of 4-6 years old (Kemendikbud, 2015). These ages can be said as a sensitive age because the physical and psychological maturation of children is ready to respond the stimulus from the environment (Israwati, 2017; Musyarofah, 2017). In which, the children tend to be more controlling their own world based on what they absorb from their surroundings. Since that they are young learner, Piaget (1929) in Kesselring \& Müller (2011) stated that they are egocentrics in which they only think on oneself without minding their surroundings. When they find something which are more interesting, they will be busy with themselves which lead them to do disruptive behavior. Disruptive behaviors are known as overlapping activities in the form of interrupting and arguing, disrespect for classroom rules and procedures, and disturbing classroom's members done by students in the classroom (Bowen, Jenson, \& Clark, 2004). Based on previous study conducted by Ghazi, Shahzada, Tariq, \& Khan (2013; Tiwari \& Panwar (2014; Yusoff \& Mansor (2016), the common disruptive behaviors done by students in classroom were disturbing friends, taking others' belonging, making noises, talking out of turn, out of seat, sleeping during the lesson, chitchatting to one another, and disobeying teacher's instruction.

Classroom condition and environment influence students to do disruptive behavior (Ghazi et al., 2013; Karakaya \& Tufan, 2018; Şanll, 2019). The continuance of disruptive behaviors makes a negative impact on the development of children. Classrooms with frequent disruptive behaviors have less academic engagement, and the students who are in disruptive behaviors tend to have lower grades (Bowen et al., 2004; Karakaya \& Tufan, 2018; Lopes, Silva, Oliveira, Sass, \& Martin, 2017; Martella \& Merchand-Martella, 2015; Oliver, Wehby, \& Reschly, 2011). Letting the students to do such a disruptive behavior will give a bad impact for themselves. As a result, it will impact their learning outcomes at school. Moreover, the one thing that becomes a concern, it will also distract children development since they are as a young learner. 
As a classroom manager, a teacher as an important role in overcoming those kinds of disruptive behavior problem that happens during the learning process. If the students with disruptive behavior do not have a proper reaction from the teacher, they may tend to do those kinds of behavior continuously. Teacher behavior is affect students character especially in disruptive behavior (Apriani, 2019; Apriani, 2019). Therefore, teacher's command is needed here in order to decrease disruptive behavior in classroom. Matheson \& Shriver (2005) revealed that effective command is a prominent aspect in managing classroom behavior because through effective command it will help teachers to direct and attract students' attention to stop activity that might be harmful for students and their surroundings.

Based on the preliminary observation conducted in TK Aura Sukma Insani, teachers in this kindergarten school have provided several commands for their students. However, the teachers stated that there was no consideration in stating the command because they have no underlying theory about it in which made the commands given sometimes worked and sometimes just temporarily stopped students' disruptive behaviors. Thus, knowing types of command used is needed in order to make the teachers easier to classify which command could be effective to overcome certain disruptive behavior. Therefore, it will give an effect on students' disruptive behavior. In line with this, (Bertsch, Houlihan, Lenz, \& Patte, 2009) proposed several types of command that can be used by teachers to overcome ongoing disruptive behaviors done by students in the classroom. These type of commands including interrogation command, question command, regular command, indirect command, stop command, don't command, negative command, and other command.

Based on aforementioned statement, this study was conducted which aimed at investigating effective commands used by kindergarten teacher in teaching English for students with disruptive behavior by identifying 1) The types of disruptive behavior done by students in English class at TK Aura Sukma Insani, 2) The types of command used by kindergarten teachers in English class at TK Aura Sukma Insani, and 3) 
The commands which are effective in overcoming students with disruptive behavior.

\section{THEORETICAL FRAMEWORK}

In the real classroom situation, the teacher may find numerous behavior problems that are coming from the students. Those problems that bother the teaching and learning process are known as classroom disruptive behavior. Moreover, classroom with frequent disruptive behavior leads the teacher to make a continual comment to students with disruptive behavior (Sun \& Shek, 2012) which indirectly impacts other students who behave normally. Disruptive behaviors are known as overlapping activities in the form of interrupting and arguing, disrespect for classroom rules and procedures, and disturbing classroom's members done by students in the classroom (Bowen et al., 2004) for example: arguing to each other, interrupting classroom's members, wandering around the room, and disturbing classmates' work. In line with this, Nicholas (1998) in Bowen et al. (2004) also mentioned top ten lists of the most disruptive behaviors that teachers reported were including talking out, not following direction, not respecting others, not finishing work, fighting, acting out, arguing, out of seat, tattletale, and interrupting.

Regarding to types of disruptive behavior mentioned by (Bowen et al. (2004) above, each type of disruptive behavior also has its subtypes. The first type of disruptive behavior is related to arguing/interrupting with two sub-types including arguing and interrupting. Arguing refers to an activity that involves students in arguing to one another about the topic that is not relating to the lesson in which makes the classroom's members feel bothered. Moreover, interrupting also refers to an activity done by students when they interrupt the classroom's members with inappropriate topic while explaining something.

Furthermore, the second type of disruptive behavior is disrespect for classroom rules and procedures. The sub-types of disrespect for classroom rules and procedures are derived based on classroom's stated and unstated rules. If the students are done such an activity that out of 
classroom's rules and procedure it indicates that the students doing disruptive behavior related to disrespect for classroom rules and procedures. These are the following of disruptive behavior which out of classroom's rules and procedures including chitchatting, disobeying teacher's instruction, ignoring teacher, lying on the floor, making noises, out of seat, playing, praying improperly, sitting improperly, taking out of turn, and wandering around the room in which there are eleven subtypes in total.

The last type of disruptive behavior is disrtubing classroom members. The sub-types that belong to disturbing classroom's members are classified based on activity done by the student in which this activity tends to be more disturbing he classroom's member during the learning process. Those activities that refer to disturbing classroom's member are disturbing friend, disturbing teacher, screaming, seeking attention, and taking other's belonging.

The continuance of disruptive behaviors makes a negative impact on the development of children. Classrooms with frequent disruptive behaviors have less academic engagement, and the students who are in disruptive behaviors tend to have lower grades Bowen et al., 2004; Karakaya \& Tufan, 2018; Lopes et al., 2017; Martella \& Merchand-Martella, 2015). Therefore, letting the students to do such a disruptive behavior will give a bad impact for themselves. As a result, it will impact their learning outcomes at school.

Therefore, teacher's command is needed here. The most prominent aspect that should be owned by the teacher in managing effective classroom management is providing effective commands for their students (Matheson \& Shriver, 2005). Command is a crucial aspect used by the teachers to direct and attract students' attention to stop activity that might be harmful for themselves and surroundings (Bertsch et al., 2009; Martella \& Merchand-Martella, 2015; Şanll, 2019). Through appropriate command, it will help the teacher to increase disruptive behavior problem in classroom. In line with this, Bertsch et al. (2009) proposed the types of commands based on its form: 1) interrogation command, 2) question command, 3) regular command 4) 
indirect command, 5) stop command, 6) don't command, 7) negative command, and 8) other command.

The first is interrogation command. This kind of command refers to a type of statement in the form of a question which typically used to interrogate on why the students did the ongoing behavior, for example: 'Why did you do that?' However, this type of command is used to be responded by the children verbally. The second is question command. Question command is a command in the form of a question that expects the response in a motoric way which aims at directing students' behavior, for example: 'Would you please sit down in the good position?'. The third is regular command. Regular command refers to a command that is stated directly in the form of imperative statement to stop ongoing disruptive behavior done by the students, for example in the statement 'Come here', 'Sit down please!'. The fourth is indirect command. Indirect command is the opposite of the direct commands which refers to give suggestions or options about something in order to stop ongoing disruptive behavior done by students, for example: 'I will not play the music if you still make noises.'

The next is stop command. Stop command refers to a command to stop the ongoing behavior which is typically using the word 'stop' to start the command, for example: 'stop crying', 'stop running'. The sixth is don't command. Don't command is a command that has the same purpose with stop commands but the statement stated differently. This command is usually using the word 'don't' to start the command, for example: 'don't run', 'don't disturb your friend!'. The seventh is negative command. Negative command is a command which consists of command to stop ongoing behavior but usually avoiding words 'stop' and 'don't', for example, 'Silent!'. The last is other command. Other command is a command which out of the categories mentioned above and sometimes consisting of two or more types of command, for example: calling students' name, 'Can you please stop? Fold your hands!'.

As what have been stated by Bertsch et al (2009), there are several types of command that should be known in order to give appropriate command in handling students with such kinds of disruptive behavior problem. On one hand, Knoster (2014) stated that 
effective command should be given in clear, understandable, and simple way. On the other hands, Forehand and McMahon (1981) in (Matheson \& Shriver, 2005) stated that commands can be said as effective, if that is directly stated, specific, consisting of one step, developmentally appropriate, using positive phrase, and given once. Moreover, Forehand and McMahon (1981) in Matheson \& Shriver (2005)defined effective command based on its effect on students' behavior. It can be said as effective if the students could change their behavior from disruptive to be a good student.

\section{RESEARCH METHODOLOGY}

This study referred to a descriptive study using a qualitative approach. This study was conducted in TK Aura Sukma Insani which located at Gang Mawar No. 10, Sambangan, Sukasada sub-district, Buleleng regency. The three teachers from different classes as well as 67 students from those classes including A2, A1, and toddler class were observed as the subject of this study. Meanwhile, the objects of this study were disruptive behaviors done by students and commands used by the teachers for overcoming students with disruptive behavior during the class. Observation, questionnaire, and interview were methods used in collecting the data related to this study. The instruments used including observation sheet, questionnaire, interview guide, video recorder, and voice recorder.

The obtained data were analyzed qualitatively by investigating the general commands used by the teacher and the effective command used for students with disruptive behavior. To help the researcher analyzes the data, the researcher used the technique of data analysis based on the categories of (Miles \& Huberman, 1994) in which the data analysis consists of three steps namely, data collection, data reduction, data display, and conclusion drawing. In order to increase the credibility and validity of the data, the researcher used methodological triangulation in this study. The researcher employed methodological triangulation in gaining information by conducting observation, distributing questionnaire, and conducting interview. 


\section{FINDINGS \& DISCUSSION}

The findings of this present study will be divided into several main parts regarding to the research questions of this study. Three teachers and some students in three different classes (A2, A1, and toddler class) were observed as the subject of the study. A2 class was observed on the first and fourth day of observation. A1 class was observation on the second and fifth day of observation. Toddler class was observed on third day observation. The result of observation from each objective of the study are presented as follows.

\section{Types of Disruptive Behavior Done by Students in TK Aura Sukma Insani}

The types of disruptive behavior done by students in TK Aura Sukma Insani were conducted through observation which was taken five times in three different classes. Every student in three different classes indicated done such kinds of disruptive behavior during the English class. There are three types of disruptive behavior proposed by Bowen et al., (2004); interrupting and arguing, disrespect for classroom rules and procedures, and disturbing classroom's members, used in the present study as a guidelines to identify types of disruptive behavior done by students during English class in TK Aura Sukma Insani. The result of observation were presented on the table 1 below.

Table 1.

The Occurrence of Disruptive Behavior done by Students in TK Aura Sukma Insani

\begin{tabular}{|l|l|l|l|l|l|l|l|}
\hline \multirow{2}{*}{ No } & \multirow{2}{*}{ Type of Disruptive Behavior } & \multicolumn{7}{|c|}{ Observation } \\
\cline { 3 - 7 } & I & II & III & IV & V \\
\hline \multicolumn{7}{|c|}{ Arguing and Interrupting } \\
\hline 1 & Arguing & - & - & - & - & - \\
\hline 2 & Interrupting & - & - & 2 & - & 1 \\
\hline \multicolumn{7}{|c|}{ Disrespect for Classroom Rules and Procedures } \\
\hline 1 & Chitchatting & 1 & 3 & 1 & 3 & 4 \\
\hline 2 & Disobeying teacher's instruction & 3 & 6 & 4 & 1 & 4 \\
\hline 3 & Ignoring teacher & - & 2 & 7 & 3 & 2 \\
\hline 4 & Lying on the floor & - & 2 & - & - & 3 \\
\hline
\end{tabular}




\begin{tabular}{|c|l|l|l|l|l|l|}
\hline 5 & Making noises & 1 & 2 & 6 & - & 4 \\
\hline 6 & Out of seat & 1 & 4 & 3 & - & 4 \\
\hline 7 & Playing & 1 & 1 & 7 & 2 & 4 \\
\hline 8 & Praying improperly & 1 & 3 & - & 1 & 2 \\
\hline 9 & Sitting improperly & 1 & 7 & 1 & 2 & 6 \\
\hline 10 & Taking out of turn & - & - & 1 & - & - \\
\hline 11 & Wandering around the class & - & - & 2 & - & 1 \\
\hline \multicolumn{7}{|c|}{ Disturbing Classroom's Members } \\
\hline 1 & Disturbing friend & - & 3 & 6 & 3 & 2 \\
\hline 2 & Disturbing teacher & - & - & - & - & - \\
\hline 3 & Screaming & 2 & 1 & 1 & - & - \\
\hline 4 & Seeking attention & - & - & 2 & 1 & 3 \\
\hline 5 & Taking other's belonging & - & - & 1 & - & - \\
\hline \multicolumn{7}{|c|}{ Total } \\
\hline
\end{tabular}

All of the disruptive behaviors done by students in TK Aura Sukma Insani during five times of observation were displayed on the table 1 above. The result showed that there were totally 145 disruptive behaviors done by the student which had accumulated with the three types of disruptive behavior proposed by Bowen et al. (2004); arguing and interrupting, disrespect for classroom rules and procedures, and disturbing classroom's members. From all common behaviors mentioned on the table above, it could be known that arguing and disturbing friend were not done by the students during the learning process. Moreover, types of disruptive behavior done by students in A1 and toddler class were more varied than A2. For an example, interrupting and wandering around the class were two of common behaviors done by students in A1 and toddler class while students in A2 class were not done those such kinds of behavior. In line with this, students in A2 class also indicated that they have less disruptive behaviors done during the learning process which could be seen on the occurrence of disruptive behavior on first and fourth observation. Overall, from the data displayed above, it could be concluded that the types of disruptive behavior related to disrespect for classroom rules and procedures including chitchatting, disobeying teacher's instruction, ignoring teacher, lying on the floor, making noises, out of seat, playing, 
praying improperly, sitting improperly, taking out of turn, and wandering around the class was the most frequent disruptive behavior done by students in in TK Aura Sukma Insani which dominated on each observation.

Disruptive behaviors are known as overlapping activities in the form of interrupting and arguing, disrespect for classroom rules and procedures, and disturbing classroom's members done by students in the classroom (Bowen et al., 2004). Since this study was conducted in kindergarten school, the students that were being observed were around four to five years old. Generally, at this age the students tend to have their own worlds which make them busy with themselves. Indirectly, it leads students to do such kind of disruptive behaviors during the learning process. From the data gathered in interview, the teachers stated their opinions about how disruptive behavior could happen during the class. One of teacher's response can be seen on the following quotation.

"The students tend to get bored quickly. Moreover, this age is still around 4-5 years old, so their concentrations is quite weak. They are more comfortable doing something that they want to do especially do such kinds of thing together with the friends." (Teacher 3 )

Regarding to teacher's response on how the disruptive could happened during the class, it showed that the students mostly had lack of concentrations which made them easy to get bored. Theoretically, Herbert \& Wookey (2004) stated that children in the age around four to five years old only have 13 to 15 minutes for their attention spans. Therefore, because of this short of attention span, it makes the students easy to lose their focus which tended to be distracted with their surroundings. Conclusively, it can be said that the theory and findings are in line that students in age of four to five have short of attention spans which makes them easy to get bored and leads the students to do disruptive behavior when they have less interest with the lesson.

Ghazi et al., (2013); Karakaya \& Tufan (2018); Şanlı (2019) on their research stated that classroom condition and environment also 
influence students to do disruptive behavior. Moreover, this age also can be said as a sensitive age because the physical and psychological maturation of children is ready to respond the stimulus from the environment (Israwati, 2017; Musyarofah, 2017). In line with the observation, disruptive behavior mostly appeared when the teacher only paid attention to certain students. For example, in a lesson, the teacher asked students one by one to coming in front of the class to explain something. Hence, the rest of the students who waited the turn were lack of teacher's attention. Therefore, they had nothing to do while waiting their turn. Simply, when they found that the ongoing lesson was not that interesting and lack of teacher's attention, they would prefer to do something that they loves which leaded to do disruptive behavior. It can be said that poor classroom condition and environment leads students to do disruptive behavior.

In line with this, from the observation result indicated disrespect for classroom rules and procedures was the most frequent disruptive behavior done by students in TK Aura Sukma Insani during the observation. This result are supported by Nicholas (1998) in Bowen et al., (2004). Based on survey that he was conducted, he stated top ten lists of common problem behaviors that most teachers report, three of them are making noises, disobeying teacher's instruction, and out of seat in which those behaviors belong to disrespect for classroom rules and procedures. Moreover, there were also some previous studies conducted by Ghazi et al., (2013); Tiwari \& Panwar (2014); Yusoff \& Mansor (2016) discovering typical disruptive behaviors done by students during the learning process. Those disruptive behavior found including sleeping during the lesson, chitchatting to one another during the lesson, taking out of turn, disobeying teacher's instruction, ignoring teacher, out of seat, making disturbing noises, and wandering around the room in which all of those disruptive behaviors also belonged to disrespect for classroom rules and procedures. Therefore, it can be concluded that disrespect for classroom rules and procedures is the most frequent disruptive behavior appeared in this present study which is also in line with the theory and previous studies used in this present study. 


\section{Types of Command Used by Teachers in TK Aura Sukma Insani}

Besides of identifying the type of disruptive behaviors done by students during the class, observation was also used by the researcher to identify types of command used by the teachers during teaching English in TK Aura Sukma Insani. There are eight types of command proposed by Bertsch et al. (2009): interrogation command, question command, regular command, indirect command, stop command, don't command, negative command, and other command which used to help the researcher to identify types of command used by the teachers. The result of the observation were presented on the figure below.

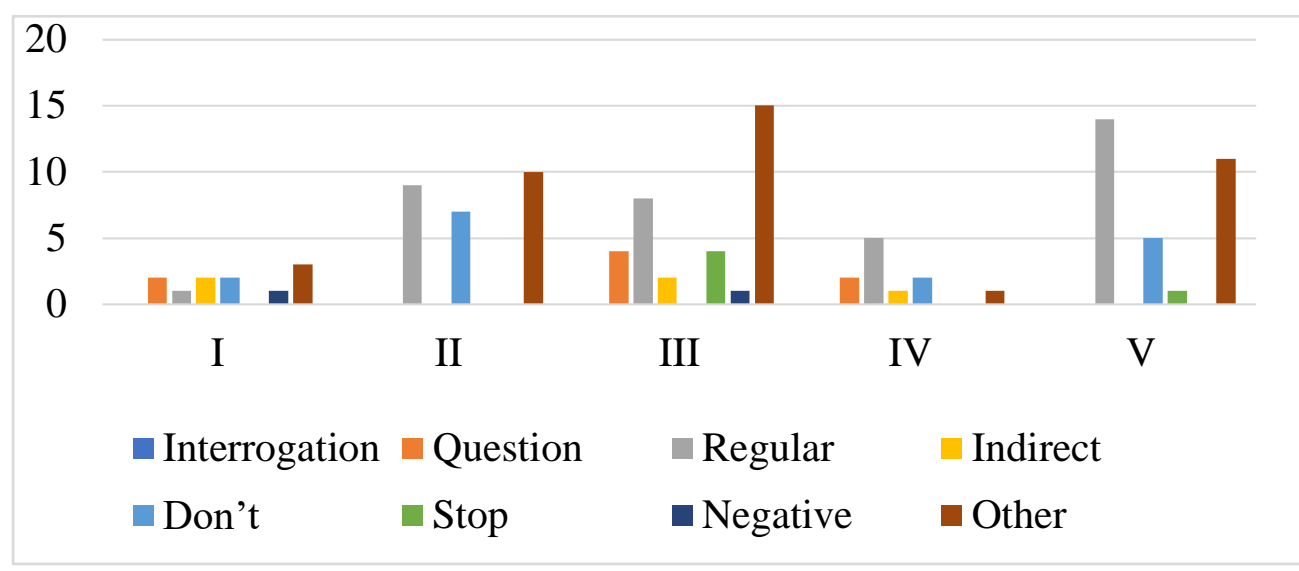

Figure 1

The types of command used by teachers in TK Aura Sukma Insani

Note:

A2 class : Observation I \& IV

A1 class : Observation II \& V

Toodler : Observation III

The figure 1 above displayed the types of command used by the teachers in TK Aura Sukma Insani during five times of observation which showed certain commands that used frequently on each observation. There were 113 commands in total used by teachers during the observations which had accumulated with eight types of command 
proposed by Bertsch et al., (2009). From each observation that types of command used by $\mathrm{T}_{2}$ in $\mathrm{A} 1$ class did not that vary than other teachers in which $\mathrm{T}_{2}$ only used four from eight types of command proposed by Bertsch et al., (2009). Meanwhile, the other teachers used around six to seven types of command. Moreover, when it compared to the total occurrence of disruptive behavior, it found that there were 32 disruptive behavior done by students which were not given a command by the teachers. Another thing, from each observation regular command and other command reached highest ranges which indicated those types of command were the most frequent commands used by the teachers in TK Aura Sukma Insani. However, interrogation command was not found during the observation which indicated that interrogation command was not a choice of the teachers in TK Aura Sukma Insani for overcoming students with disruptive behavior.

In line with this, in interview, the teacher also agreed that other command and regular command were the most frequent commands used by them which could be seen on the following quotations.

\footnotetext{
"The easiest and simple command is my choice. Maybe, regular command and calling students' name I used the most." (Teacher 2) "Actually, calling students' name directly is enough to distract their attention to make them behave well. Does it belong to other command? Yes, calling name is the most frequent command I used." (Teacher 3)
}

Based on their responses, they stated that other command and regular command were the simplest and easiest command to be used which made students easy to understand what the teachers intended. The teachers also stated that by only calling the students' name which belonged to other command, is enough to attract students' attention the teacher. That is not only teachers' opinion, but it also can be proven from observation time, the researcher found that the students with disruptive behavior were paying attention or following teacher's instruction when the teachers only called the students' by their name. 
Besides, a regular command was also the most frequent command after other command used by the teacher in overcoming students with disruptive behavior. The regular command can be known as a command which stated directly in the form of imperative statement to stop ongoing disruptive behavior done by the students (Bertsch et al., 2009). Simply, this command is straight to the point about what students should do. For example, there is a student who sits down improperly and the teacher gives a command in the form of regular command; 'Sit down in the good position, please'.Lentini, Vaughn, \& Fox (2005) stated that it would be better if the teachers ask students about what to do rather than what not to do. For instance, it makes the student understand that he should stop his ongoing behavior and sit down in the good position as what instructed by the teacher.

\section{The Effectiveness of Command Used by Teachers in TK Aura Sukma Insani}

Previously, the researcher has explained the types of disruptive behavior done by students and also types of command used by teachers for overcoming students with those such kinds of disruptive behavior in TK Aura Sukma Insani. This part will be focused on the effectiveness of the command based on students' responses to the commands given by the teachers. Through the students' responses, the researcher could find out whether or not the commands given were effective.Therefore, the result of the effectiveness of the commands based on students' responses during the observation were distributed as follows.

Table 2.

The Effectiveness of Commands based on Students' Responses in TK Aura Sukma Insani

\begin{tabular}{|l|l|c|c|c|c|c|c|c|c|c|c|}
\hline \multirow{2}{*}{ No } & \multirow{2}{*}{$\begin{array}{c}\text { Types of } \\
\text { Command }\end{array}$} & \multicolumn{10}{|c|}{ Observation } \\
\cline { 3 - 13 } & & \multicolumn{2}{|c|}{ I } & \multicolumn{1}{|c|}{ II } & \multicolumn{1}{|c|}{ III } & \multicolumn{2}{|c|}{ IV } & \multicolumn{2}{|c|}{ V } \\
\cline { 3 - 13 } & & E & I & E & I & E & I & E & I & E & I \\
\hline 1 & Interrogation & - & - & - & - & - & - & - & - & - & - \\
\hline 2 & Question & 2 & - & - & - & 4 & - & 2 & - & - & - \\
\hline 3 & Regular & 1 & - & 9 & - & 8 & 1 & 5 & - & 14 & - \\
\hline
\end{tabular}




\begin{tabular}{|l|l|c|c|c|c|c|c|c|c|c|c|}
\hline 4 & Indirect & 2 & - & - & - & 2 & - & 1 & - & - & - \\
\hline 5 & Don't & 2 & - & 7 & - & - & - & 2 & - & 5 & - \\
\hline 6 & Stop & - & - & - & - & 4 & - & - & - & 1 & - \\
\hline 7 & Negative & 1 & - & - & - & 1 & - & - & - & - & - \\
\hline 8 & Other & 3 & - & 9 & 1 & 13 & - & 1 & - & 11 & - \\
\hline
\end{tabular}

Note:

A2 class : Observation I \& IV

A2 class : Observation II \& V

Toddler : Observation III

Table 2 showed the effectiveness commands from each observation conducted in TK Aura Sukma Insani. From the table indicated that the commands given to the students were mostly effective. However, 2 out of 113 from the total command were ineffective which appeared in two different times of observation. Those command belonged to regular command on second observation (A1 class) and other command on the third observation (toddler class). In this case, the other command was used by the teacher for overcoming student who was sitting improperly. Although the teacher had thrown the command, the student still sat improperly. Besides, regular command was used to stop students who were wandering around the class while waiting their friends finished the tasks given by the teacher. Based on its effect on students' behavior, it indicated that the commands given were ineffective.

In line with this, when the researcher discovering the video of observation, it found that the problem was from the students' factor. The students were pretending to not hear teachers' commands. Therefore, they tended to not following teachers' commands to sit down in the good position. Piaget (1929) in Kesselring \& Müller (2011) stated that early childhood students are egocentrics in which they place themselves as a center and thinking only on oneself without minding their surroundings. In this case, it can be said that the students only focused 
on their own selves to do something more interesting when the teachers gave them a command.

Regarding to the most frequent types of command used, the teachers also stated that regular command and other command were the most effective commands in overcoming students' disruptive behavior. They explained that all of the commands that give a positive effect on students' behavior could be said as effective command in which this statement is in line with theory stated by Forehand and McMahon (1981) in Matheson \& Shriver (2005). He defined that a command could be said as an effective command based on its effect on students' behavior. Simply, it can be said as effective if the students could change their behavior from disruptive to be a good student. The same things also found in observation, all the commands used by the teachers gave effects on students' behavior. The students paid attention and followed teachers' instruction to stop ongoing behaviors. In addition, it can be said another types of command including question command, indirect command, don't command, stop command, and negative were also effective to overcome students' disruptive behavior.

Moreover, from all the types of commands proposed by Bertsch et al. (2009), the teachers stated that regular command and other command were the most effective commands in overcoming students' disruptive behavior. The teachers' statement can be seen on the following quotations.

"If you are asking the most effective, I think is regular command. You might have noticed during the observation, I prefer to use it because it was very clear and easy to be understood." (Teacher 1). "Calling students' name is very effective because could notice them directly. Moreover, it is very simple yet clear. The students are also easy to understand." (Teacher 2).

From to teachers' responses about effective command, they stated that regular commands and other commands which referred to calling students' name were the most effective command because those type of commands were very simple and easy to be understood by the 
students. Those types of command were also straight to the point and noticed the students who were doing disruptive behavior directly which is in line with the theory stated by Knoster (2014) that effective command should be given in clear, understandable, and simple way. Therefore, the students could get the point and follow what the teachers instructed.

\section{CONCLUSION}

Command can be defined as an effective command based on its effect on students' behavior of the students show positive response to their behaviors, it means that the commands given are effective. Based on students responses who given commands by teachers it can be concluded that mostly all of the commands used were effective to overcome students disruptive behavior because after the commands given, the students followed teachers' instruction to stop ongoing disruptive behaviors. However, there were two commands that were ineffective. It was because of students' factor; they are egocentrics in which they place themselves as a center and thinking only on oneself without minding their surroundings.

Therefore, commands given did not give any effect on students' disruptive behavior in which they were still doing their ongoing disruptive behavior although they had given commands. In giving a command, the teachers should concern on how the commands given to the students. Since the students are still young learners, the commands given should be in clear, understandable, and simple ways. It was proven in this present study that only calling students by their name could notice them and stop their ongoing disruptive behavior. Moreover, asking students what to do is better than what not to do. Therefore, the way on how the teachers giving a command to students should be given more attention in order that easy to be understood by the students involved.

Furthermore, the researcher hopes that there will be other researchers to conduct this study and spare enough time in collecting the data. Therefore, a lot of things will be discovered during conducting 
the research. Besides, the other researchers are also suggested to find out how a command given to students with disruptive behavior not guarantee them to not doing disruptive behavior in further. After all, those suggestions are expected to give contribution to the field especially in effective commands used to overcome students' disruptive behavior during the learning process.

\section{REFERENCES}

Ali, A., \& Gracey, D. (2013). Dealing with Student Disruptive Behavior in the Classroom - A Case Example of the Coordination between Faculty and Assistant Dean for Academics. Issue in Informing Science and Information Technology, 10, 1-15. Retrieved from http://iisit.org/Vol10/IISITv10p001-015Ali0124.pdf.

Apriani, E. (2016). A New Literacy: The Role of Technology to Develop Student's Character. Ta'dib:Journal of Islamic Education Uurnal $\begin{array}{llll}\text { Pendidikan } & \text { Islam), 21(1), } & 59 & -\end{array}$ https://doi.org/https://doi.org/10.19109/tjie.v21i1.742.

Apriani, E., Supardan, D., Sartika, E., Suparjo, S., \& Hakim, I. N. (2019). UTILIZING ICT TO DEVELOP STUDENT'S LANGUAGE ETHIC AT ISLAMIC UNIVERSITY. POTENSIA: Jurnal Kependidikan Islam, 5(1), 1-14.

Bertsch, K. M., Houlihan, D., Lenz, M. A., \& Patte, C. A. (2009). Teachers' Commands and Their Role in Preschool Classrooms. Electronic Journal of Research in Education Psychology, 7(17), 133-162.

Bowen, J., Jenson, W., \& Clark, E. (2004). School-based interventions for students with behavior problems. New York: Springer Science+Business Media. https://doi.org/10.1007/978-1-44199102-7

Ghazi, S. R., Shahzada, G., Tariq, M., \& Khan, A. Q. (2013). Types and Causes of Students' Disruptive Behavior in Classroom at Secondary Level in Khyber Pakhtunkhwa, Pakistan. American Journal of Education Research, $1(9)$, 350-354. https://doi.org/10.12691/education-1-9-1 
Herbert, M., \& Wookey, J. (2004). Managing children's disruptive behavior: a guide for practitioners working with parents and foster parents. London: British Library Cataloguing in Publication Data.

Israwati. (2017). Pengelolaan Ruang Kelas Pendidikan Anak Usia Dini Pada Kelompok B di Taman Kanak-Kanak. Jurnal Serambi Ilmu, 119-124. Retrieved from http://ojs.serambimekkah.ac.id/index.php/serambiilmu/article/download/453/415

Karakaya, E. G., \& Tufan, M. (2018). Social Skills, Problem Behaviors and Classroom Management in Inclusive Preschool Settings. Journal of Education and Training Studies, 6(5), 123-134. https://doi.org/10.11114/jets.v6i5.3076

Kemendikbud. (2015). Peraturan Menteri Pendidikan dan Kebudayaan Republik Indonesia Nomor 84 Tahun 2014 Tentang Pendirian Satuan Pendidikan Anak Usia Dini. Retrieved from http://simpuh.kemenag.go.id/regulasi/permendikbud_84_14.pdf Kesselring, T., \& Müller, U. (2011). The Concept of Egocentrism in Context of Piaget's Theory. New Ideas in Psychology, 29(3), 327345. https://doi.org/10.1016/j.newideapsych.2010.03.008

Knoster, T. (2014). The teacher's pocket guide for effective classroom management (2nd ed.). Retrieved from http://archive.brookespublishing.com/documents/knosterclassroom-management.pdf

Lentini, R., Vaughn, B. J., \& Fox, L. (2005). Teaching tools for young children with challenging behavior. Retrieved from https://vkrp.virginia.edu/content/pdfs/3. Communication is key.pdf

Lopes, J., Silva, E., Oliveira, C., Sass, D., \& Martin, N. (2017). Teacher's Classroom Management Behavior and Students' Classroom Misbehavior: A Study with 5th through 9th - Grade Students. Electronic Journal of Research in Education Psychology, 15(3), 467490. Retrieved from https://www.researchgate.net/profile/Joao_Lopes4/publication/3 23171089_Teacher\%27s_Classroom_Management_Behavior_and_St 
udents\%27_Classroom_Misbehavior_A_Study_with_5th_through_9t h_-_Grade_Students/links/5aba15d845851515f5a13514/TeachersClassroom-Management-Behavior-and-Students-ClassroomMisbehavior-A-Study-with-5th-through-9th-GradeStudents.pdf?origin=publication_detail

Martella, R., \& Merchand-Martella, N. (2015). Improving Classroom Behavior Through Effective Instruction: An Illustrative Program Example Using SRA FLEX Literacy. Education and Treatment of Children, 38(2), 241-272. Retrieved from http://info.mheducation.com/rs/128-SJW-

347/images/Improving_Classroom_Behavior_Through_Effective_In struction_An_Illustrative_Program_Example_Using_SRA_FLEX_Liter acy.pdf

Matheson, A. S., \& Shriver, M. D. (2005). Training Teachers to Give Effective Commands: Effects on Student Compliance and Academic Behaviors. School Psychology Review, 32(2). Retrieved from https://www.researchgate.net/profile/Andrea_Matheson/publicati on/282690438_Training_Teachers_to_Give_Effective_Commands_Ef fects_on_Student_Compliance_and_Academic_Behaviors/links/56d0 625b08aeb52500cd720f/Training-Teachers-to-Give-Effective-

Commands-Effects-on-Student-Compliance-and-AcademicBehaviors.pdf?origin=publication_detail

Miles, M. B., \& Huberman, A. M. (1994). Qualitative data analysis (2nd ed.). California: Sage Publications. Retrieved from https://vivauniversity.files.wordpress.com/2013/11/milesandhub erman1994.pdf

Musyarofah. (2017). Pengembangan Aspek Sosial Anak Usia Dini di Taman Kanak Kanak Aba IV Mangli Jember Tahun 2016. Interdisciplinary Journal of Communication, 2(1), 99-121. Retrieved from https://doi.org/10.18326/inject.v2i1.99-122

Oliver, R. M., Wehby, J. H., \& Reschly, D. J. (2011). Teacher classroom management practices: effects on disruptive or aggressive student behavior. USA: The Campbell Collaboration. https://doi.org/10.4073/csr.2011.4

Şanlı, Ö. (2019). An Evaluation of the Teachers' Classroom Management 
Problems. Academic Journals, 14(8), 282-292. https://doi.org/10.5897/ERR2019.3712

Sun, R. C. F., \& Shek, D. T. L. (2012). Student Classroom Misbehavior: An Exploratory Study Based on Teachers' Perceptions. The Scientific World Journal, 1-8. https://doi.org/10.1100/2012/208907

Tiwari, G., \& Panwar, H. (2014). A Study on the Classroom Behaviour Problems at Secondary Level. American Research Thoughts, 1(1), 514-536. Retrieved from https://www.researchgate.net/profile/Gyanendra_Tiwari/publicat ion/269710972_A_Study_on_the_classroom_behaviour_Problems_at _secondary_level/links/5495037e0cf2ec1337581e04/A-Study-onthe-classroom-behaviour-Problems-at-secondarylevel.pdf?origin=publication_detail

Yusoff, W., \& Mansor, N. (2016). The Effectiveness of Strategies Used by Teachers to Manage Disruptivw Classroom Behaviors: A Case Study at a Religious School in Rawang, Selangor. Journal of Educational Studies, 1(4), 133-150. 
202 | ENGLISH FRANCA, Vol. 4, No. 2, 2020

EMPTY PAGE 